International Research Journal of Management, IT \& Social Sciences
Available online at https://sloap.org/journals/index.php/irjmis/
Vol. 7 No. 6, November 2020, pages: 116-123
ISSN: 2395-7492
https://doi.org/10.21744/irjmis.v7n6.1021

\title{
The Role of Development Entrepreneurial Orientation and Market Orientation in Improving the Performance of Creative Industry SMEs in Denpasar
}

\begin{tabular}{ll} 
Article history: & $\begin{array}{c}\text { Ida Ayu Agung Idawati } \\
\text { Ade Ruly Sumartini }\end{array}$ \\
\hline Submitted: 09 August 2020 & Abstract \\
Revised: 18 September 2020 & $\begin{array}{l}\text { Bali is an area that relies on the tourism industry. The management of the } \\
\text { tourism industry cannot be separated from other sectors, such as the creative } \\
\text { Accepted: } 27 \text { October } 2020\end{array}$ \\
industry. The creative industry is a supporter of economic growth in increasing \\
employment opportunities and reducing the low population in Indonesia.
\end{tabular}

International research journal of management, IT and social sciences (C) 2020. This is an open access article under the CC BY-NC-ND license (https://creativecommons.org/licenses/by-nc-nd/4.0/).

\section{Corresponding author:}

Ida Ayu Agung Idawati,

Warmadewa University, Denpasar, Indonesia.

Email address: dayuagung84@gmail.com

\footnotetext{
${ }^{a}$ Warmadewa University, Denpasar, Indonesia

${ }^{\mathrm{b}}$ Warmadewa University, Denpasar, Indonesia 


\section{Introduction}

Indonesia's economic growth in the last three years has increased from year to year. The Indonesian economy in 2016 grew by 5.02 percent, higher than the achievement in 2015, which was only 4.73 percent. In 2017 the Indonesian economy grew by 5.06 percent, and in 2018 the Indonesian economy grew by 5.17 percent (www.bps.go.id, July 20, 2019). One of the sectors that affect Indonesia's economic growth is the Micro, Small, and Medium Enterprises sector, commonly called SMEs. SMEs have played a role in the financial recovery process since the 1998 monetary crisis. The existence of SMEs at that time can absorb labor and as a driver of economic growth.

The government has declared 2009 to be the year of the creative industry. The creative sector is believed to be a driving force for the entire industry amid the threat of a slowdown in the economy due to the global crisis (Wicaksono \& Nuvriasari, 2012; Ghosh, 2016). The creative sector can have a positive impact in supporting economic growth, increasing employment, and reducing the low population in Indonesia. The development of the creative sector towards Gross Domestic Product (GDP) in Bali Province in 2016 reached 7.17 percent, the highest in Indonesia compared to other provinces. Culinary, fashion and creative arts are Bali's mainstay sub-sectors with a proportion of 18 percent and 15.4 percent, respectively (nusabali.com, July 20, 2019).

Bali has the potential to develop the creative industry. As it is well known that Bali is a tourist destination for most domestic and foreign tourists. Bali is an area that relies on the tourism industry. The creative sector is one of the supporting factors for the tourism industry. Therefore it is necessary to increase the performance in this sector. Improving the performance of the creative industry cannot be separated from the critical role of human resources. Creative industry players are expected to know the entrepreneurial orientation and market orientation to improve the performance of the creative industry concerned.

The main concern of this research is the improvement of the performance of SMEs through the development of entrepreneurial orientation and market orientation. This study focused on Small and Medium Enterprises (SMEs) in Denpasar City. Version is one of the keys to exist in business competition. Entrepreneurial orientation is one of the factors that affect performance. Entrepreneurial orientation (EO) refers to "The processes, practices, and decisionmaking activities that lead to new entry" (Lumpkin \& Dess, 1996). EO is revealed through firm-level characteristics as summarized by Miller \& Friesen (1983): "An entrepreneurial firm is one that engages in product-market innovation, undertakes somewhat risky ventures, and is first to come up with 'proactive' innovations beating competitors to the punch." (Wang, 2008).

Several previous studies have shown different results. Awang et al. (2009); Hassim et al. (2011); Mahmood \& Hanafi (2013), stated a positive relationship between entrepreneurial orientation and business performance. In contrast to the research results of Aulia et al. (2019); Hatta (2015); Priatin et al. (2017), states that entrepreneurial orientation does not affect marketing performance.

Apart from entrepreneurial orientation, it is also necessary to pay attention to market orientation. A market orientation, as corporate culture, characterizes an organization's disposition to deliver superior value to its customers continuously (Slater \& Narver, 1994a). Several previous studies related to market orientation and performance gave inconsistent results. Research from Chairani (2016), states that the market orientation of business actors can significantly influence marketing performance. Elwisam \& Lestari, (2019), show that market orientation has a positive effect on marketing performance. Research from Hartini (2015), states that there is no relationship between market orientation and company performance. This result is supported by the study of Solomon et al. (2016), who also stated that market orientation (MO) is negatively related to SMEs.

Based on the background description and research gap above, the formulation of the problem in this study is arranged as follows:

1) How is the influence of entrepreneurial orientation development in improving the performance of creative industry SMEs in Denpasar City?

2) How is the influence of market orientation development in improving the performance of creative industry SMEs in Denpasar City?

3) Which orientation has the most dominant influence on improving the performance of creative industry SMEs in Denpasar City?

4) How are the efforts to improve the performance of creative industry SMEs in Denpasar City?

Idawati, I. A. A. ., \& Sumartini, A. R. . (2020). The role of development entrepreneurial orientation and market orientation in improving the performance of creative industry SMEs in Denpasar. International Research Journal of Management, IT and Social Sciences, 7(6), 116-123. https://doi.org/10.21744/irjmis.v7n6.1021 
Literature review

Each entrepreneurial orientation dimension affected firm performance differently (Kreiser et al. 2002; Lumpkin \& Dess, 2001). Several studies have shown that entrepreneurial orientation affects company performance. Fairoz et al. (2010), said that there were positive correlations among pro-activeness and entrepreneurial orientation with business performance. This result is supported by Abebe (2014); Kajalo \& Lindblom (2015); Lumpkin \& Dess (1996) and Amin et al. (2016), who found that there is a positive and significant relationship between entrepreneurial orientation and performance (Susila \& Suparna, 2016).

H1: Entrepreneurial orientation has a positive and significant effect on the performance of SMEs

Market orientation and market orientation indicators (market knowledge, consumer orientation, competitor orientation, coordination with labor, and marketing implementation) had a significant and positive relationship to business performance (Nurhayati et al., 2020). These results are supported by research by Kohli \& Jaworski (1990); Pulendran et al. (2000); Zhou et al. (2009); Morgan et al. (2009), which concluded that market orientation has a positive effect on firm performance.

The consumer orientation is similar in definition to a "market orientation" as defined by Kohli \& Jaworski (1990) because it begins and ends with the needs of the customer. For small firms, market orientation can also help to improve performance (Souisa, 2018).

H2: Market orientation has a positive and significant effect on the performance of SMEs

\section{Materials and Methods}

The focus of this research is the understanding of market orientation and entrepreneurial orientation and their effects on the performance of SMEs. The population in this study were SMEs (Lee \& Peterson, 2000; Keh et al., 2007; Avlonitis \& Salavou, 2007). Creative Industry in the fashion and handicraft subsector. Convenience sampling is a method of determining the sample and obtained 40 respondents from fashion and craft SMEs as the research sample. We are collecting research data using a questionnaire method. The questionnaire contains 27 questions, where each variable consists of 9 items. The questionnaire is addressed to the owners or managers of related SMEs. The analysis technique using multiple linear regression analysis assisted by the SPSS program. The validity test and the instrument test needs to be done before continuing the other investigation. It is essential to test research instruments to determine whether the data in this study are valid and reliable.

The provision of an instrument is said to be valid if it has a Pearson Product Moment correlation coefficient ( $\mathrm{r}$ ) $>0.3$ with an alpha of 0.05 (Sugiyono, 2014). An instrument is reliable if it has an alpha coefficient $(\alpha)$ greater than 0.60 (Sugiyono, 2014). The normality test aims to test whether, in the regression model, the disturbing or residual variables have a normal distribution. Multicollinearity test seeks to try whether the regression model found a correlation between independent variables. The heteroscedasticity test aims to test whether the regression model occurs. This multiple linear regression model is used to determine the effect of the dependent variable with two or more independent variables.

The regression equation used is:

$\mathrm{Y}=\mathrm{a}+\mathrm{b} 1 \mathrm{X} 1+\mathrm{b} 2 \mathrm{X} 2+\mathrm{e}$

Notation:

$\mathrm{Y}=$ SMEs Performance

$\mathrm{X}_{1}=$ Entrepreneurial Orientation

$\mathrm{X}_{2}=$ Market Orientation

$b_{1}=$ Regression Coefficient of Entrepreneurial Orientation $\left(\mathrm{X}_{1}\right)$

$\mathrm{b}_{2}=$ Regression Coefficient Market Orientation $\left(\mathrm{X}_{2}\right)$

$\mathrm{e}=$ Error 


\section{Results and Discussions}

The results of the validity test showed the Pearson Correlation value is above 0.3, and the Sig 2-Tailed Value is below 0.05 , which can be concluded that $\mathrm{X}_{1}$ (entrepreneurial orientation), $\mathrm{X}_{2}$ (market orientation), and $\mathrm{Y}$ (SMES Performance) are valid. The reliability test results showed that Cronbach alpha value for each variable is $0.794\left(\mathrm{X}_{1}\right)$, $0.954(\mathrm{X} 2)$, and $0.601(\mathrm{Y})$ indicates the value is more than 0.6 so that it can be concluded that the research variables in this study are reliable. Normality test results show that the value of Asymp. Sig. (2 tailed) is 0,200. That value shows that the variables in this study are normally distributed. Based on the table below, all variables have Tolerance values of more than 0.10 and VIF of less than 10. These results indicate that in the regression model, there is no multicollinearity between variables.

Table 1

Multicollinearity test result

\begin{tabular}{lll}
\hline Variable & Tolerance & VIF \\
\hline X1 & 0.990 & 1.010 \\
X2 & 0.990 & 1.010 \\
\hline
\end{tabular}

The test results show that each independent variable, entrepreneurial orientation $=0.160$, and market orientation variable $=0.105$, has a significant level above 0.05 . Then it can be concluded that there are no symptoms of heteroscedasticity in the regression model used.

Table 2

Regression result

\begin{tabular}{llll}
\hline & Beta & $\mathrm{t}$ & Sig. \\
\hline Constant & 33.674 & & \\
X1 & -0.123 & -1.100 & 0.278 \\
X2 & 0,223 & 3.867 & 0.000 \\
\hline
\end{tabular}

Based on the table above, a multiple regression equation is as follows:

$\mathrm{Y}=33.674-0.123 \mathrm{X} 1+0.223 \mathrm{X} 2+\mathrm{e}$

That regression equation can be described as follows:

$\alpha=33.674$ (Constant);

When entrepreneurial orientation $\left(\mathrm{X}_{1}\right)$ and market orientation $\left(\mathrm{X}_{2}\right)$ are constant or 0 , then $\mathrm{Y}$ (SMES Performance) has a value of 33.674 .

$b_{1}=-0.123$ (Coefficient of Regression $\left.X_{1}\right)$;

If the variable entrepreneurial orientation $\left(\mathrm{X}_{1}\right)$ increases by 1 unit, it impacts on $\mathrm{Y}$ (SMES Performance), which has a decrease of 0.123 assuming other variables are constant.

b2 = 0.223 (Coefficient of Regression X2) explains;

If the market orientation variable (X2) increases by 1 unit, then Y (SMEs Performance) increases by 0.223 , assuming other variables are constants. The equation of multiple linear regression analysis above shows that the direction of influence of each independent variable on the dependent variable indicated by the regression coefficients of each independent variable. The coefficients of entrepreneurial orientation $\left(\mathrm{X}_{1}\right)$ have a negative sign, which means that variables have a negative influence on the performance of the SME's performance. On the other side, the coefficient of market orientation $\left(\mathrm{X}_{2}\right)$ variables have a positive sign, which means that these variables have a direct influence on the performance of the SME's performance (Tarute \& Gatautis, 2014; Lin \& Lin, 2016).

The results of regression calculations show that the adjusted $\mathrm{R}$ square value is 0.295 . This means that 29.5 percent of the variation in SME's performance variables can be explained by the entrepreneurial orientation $\left(\mathrm{X}_{1}\right)$ and market orientation $\left(\mathrm{X}_{2}\right)$. In comparison, the remaining 70.5 percent is explained by other variables not included in this research model.

Idawati, I. A. A. ., \& Sumartini , A. R. . (2020). The role of development entrepreneurial orientation and market orientation in improving the performance of creative industry SMEs in Denpasar. International Research Journal of Management, IT and Social Sciences, 7(6), 116-123. https://doi.org/10.21744/irjmis.v7n6.1021 
a) The influence of entrepreneurial orientation $\left(X_{1}\right)$ on the performance of SMEs

The result of the $t$ value of the entrepreneurial orientation variable is - 1,100, and the significance value of the entrepreneurial orientation variable is $0.278>0.05$, meaning that the entrepreneurial orientation variable has a negative and not significant effect on SME's fashion and handicraft performance in Denpasar City. The results of this study support previous findings from the research of Frank et al. (2010); Setyawati (2013); Lumpkin \& Dess (2001), which explain that entrepreneurial orientation negatively affects business performance. Based on the descriptive analysis of each of the entrepreneurial orientation and performance variables, it can be seen that fashion and handicraft SME players in Denpasar have not maximally implemented entrepreneurial orientation. For example, inactive innovations, not too brave to take risks, so that they cannot help improve the performance of SMEs. Fashion and craft UMKM players in Denpasar also do not understand the stages and processes of implementing entrepreneurship orientation. This results shown no significant change in improving the performance of SMEs compared to existing competitors.

\section{b) The influence of market orientation $\left(X_{2}\right)$ on the performance of SMEs}

The $t$ value of the market orientation variable is 3,867 , and the significance value of the market orientation variable is $0.000<0.05$. This means that the market orientation variable has a positive and significant impact on the performance of the SMEs sub-sector of fashion and crafts in Denpasar. These results indicate that fashion and handicraft SMEs in Denpasar City has realized the importance of market orientation towards their business performance. The results of this study support previous findings from the research of Elwisam \& Lestari (2019); Hussain \& Ali (2016); Zhou et al., (2009); Morgan et al. (2009), which explain that market orientation affects positively on company performance. Based on the descriptive analysis of each indicator of the market orientation variable, it can be seen that fashion and craft SMES players have a sufficient understanding of market orientation. They have applied knowledge of market orientation well; for example, they can serve customer requests and provide fast responses to competitors' activities. Most importantly, they have also been able to meet the needs and desires of their customers.

c) The dominant orientation affects the performance of SMEs

Based on the results of data analysis, it was found that market orientation had a positive and significant effect. These results indicate that in the performance of the fashion and handicraft sub-sector SMEs in Denpasar, the direction that dominantly affects performance is market orientation. SMEs players have been able to understand and carry out the stages of the market orientation process. Starting from being aware of customer needs and wants to how to respond quickly to competitors' business activities.

d) Efforts to improve the performance of Creative Industry SME's

Several factors indeed influence the improvement in the performance of SMEs. This study looks at how entrepreneurial orientation and market orientation can affect the performance of SMEs. Based on the results that have been obtained, the effort that needs to be done is to increase the understanding of SMEs actors regarding entrepreneurial orientation. Entrepreneurial orientation still needs to be appropriately introduced and implemented by SMEs players. One of the SMES's problems is their human resources. Their willingness to learn is still lacking. They only run what is their job description regardless of SMES's performance improvements. Understanding entrepreneurial orientation will improve the ability of SMES's players to innovate, how to maintain business continuity, and how to deal with risks that may occur in running a business.

\section{Conclusion}

a) Entrepreneurial orientation has a negative and insignificant effect on the performance of SMEs in the fashion and handicraft sub-sector in Denpasar. This shows that the entrepreneurial orientation variable does not affect the performance of SMEs because of the lack of understanding of the related SMEs players on the process of implementing the entrepreneurial orientation.

b) The value of market orientation has a positive effect on the performance of SMEs in the fashion and handicraft sub-sector in Denpasar. This means that the more profound members of the organization absorb and implement the market orientation, the more performance SMEs will increase. These results indicate that SMEs players are capable of implementing market orientation. 
Suggestion

This study is limited to the increasing of performance from the influence of entrepreneurial orientation and market orientation. There are still several orientations that might influence the improvement of the performance of SMEs in the fashion and handicraft sub-sector, such as learning orientation, product innovation, and others. The sample used is still at the creative industry sub-sector level. Future research can use the creative industry sector as a whole.

Conflict of interest statement

The authors declared that they have no competing interests.

Statement of authorship

The authors have a responsibility for the conception and design of the study. The authors have approved the final article.

Acknowledgments

We are grateful to two anonymous reviewers for their valuable comments on the earlier version of this paper.

Idawati, I. A. A. ., \& Sumartini , A. R. . (2020). The role of development entrepreneurial orientation and market orientation in improving the performance of creative industry SMEs in Denpasar. International Research Journal of Management, IT and Social Sciences, 7(6), 116-123. https://doi.org/10.21744/irjmis.v7n6.1021 


\section{References}

Abebe, M. (2014). Electronic commerce adoption, entrepreneurial orientation and small-and medium-sized enterprise (SME) performance. Journal of small business and enterprise development.

Amin, M., Thurasamy, R., Aldakhil, A. M., \& Kaswuri, A. H. B. (2016). The effect of market orientation as a mediating variable in the relationship between entrepreneurial orientation and SMEs performance. Nankai Business Review International.

Aulia, R., Astuti, M., \& Ridwan, H. (2019). Meningkatkan Kinerja Pemasaran melalui Orientasi Pasar dan Orientasi Kewirausahaan. Jurnal Ilmiah Manajemen dan Bisnis, 20(1), 27-38.

Avlonitis, G. J., \& Salavou, H. E. (2007). Entrepreneurial orientation of SMEs, product innovativeness, and performance. Journal of Business Research, 60(5), 566-575. https://doi.org/10.1016/j.jbusres.2007.01.001

Awang, A., Khalid, S. A., Yusof, A. A., Kassim, K. M., Ismail, M., Zain, R. S., \& Madar, A. R. S. (2009). Entrepreneurial orientation and performance relations of Malaysian Bumiputera SMEs: The impact of some perceived environmental factors. International Journal of Business and Management, 4(9), 84-96.

Chairani, A. A. (2016). Pengaruh Orientasi Pasar Dan Kreativitas Pemasaran Terhadap Kinerja Pemasaran Pada Studi Kasus Pedagang Pakaian Jadi Di Tangerang Selatan (Doctoral dissertation, Universitas Pembangunan Nasional Veteran Jakarta).

Elwisam, E., \& Lestari, R. (2019). Penerapan Strategi Pemasaran, Inovasi Produk Kreatif Dan Orientasi Pasar Untuk Meningkatkan Kinerja Pemasaran UMKM. Jurnal Riset Manajemen dan Bisnis (JRMB) Fakultas Ekonomi UNIAT, 4(2), 277-286.

Fairoz, F. M., Hirobumi, T., \& Tanaka, Y. (2010). Entrepreneurial orientation and business performance of small and medium scale enterprises of Hambantota District Sri Lanka. Asian Social Science, 6(3), 34.

Frank, H., Kessler, A., \& Fink, M. (2010). Entrepreneurial orientation and business performance-A replication study. Schmalenbach business review, 62(2), 175-198.

Ghosh, C. (2016). The evaluation of new marketing strategy of selected home appliances. International research journal of management, IT and social sciences, 3(11), 33-38.

Hartini, S. (2015). The Effect of Market Orientation toward Firm's Innovation, Product Quality, Competitive Advantage and Firm's Performance of Small Medium Enterprise in East Java.

Hassim, A. A., Asmat-Nizam, A. T., \& Bakar, A. R. A. (2011). The effects of entrepreneurial orientation on firm organisational innovation and market orientation towards firm business performance. International on Sociality ND Economics Development. IPEDR, 10, 280-284.

Hatta, I. H. (2015). Orientasi Pasar, Orientasi Kewirausahaan, Kapabilitas Pemasaran dan Kinerja Pemasaran. Jurnal Aplikasi Manajemen, 13(4), 653-661.

Hussain, J., \& Ali, F. (2016). www.econstor.eu.

Kajalo, S., \& Lindblom, A. (2015). Market orientation, entrepreneurial orientation and business performance among small retailers. International Journal of Retail \& Distribution Management.

Keh, H. T., Nguyen, T. T. M., \& Ng, H. P. (2007). The effects of entrepreneurial orientation and marketing information on the performance of SMEs. Journal of business venturing, 22(4), 592-611. https://doi.org/10.1016/j.jbusvent.2006.05.003

Kohli, A. K., \& Jaworski, B. J. (1990). Market orientation: the construct, research propositions, and managerial implications. Journal of marketing, 54(2), 1-18.

Kreiser, P. M., Marino, L. D., \& Weaver, K. M. (2002). Assessing the psychometric properties of the entrepreneurial orientation scale: A multi-country analysis. Entrepreneurship theory and practice, 26(4), 71-93.

Lee, S. M., \& Peterson, S. J. (2000). Culture, entrepreneurial orientation, and global competitiveness. Journal of world business, 35(4), 401-416. https://doi.org/10.1016/S1090-9516(00)00045-6

Lin, F. J., \& Lin, Y. H. (2016). The effect of network relationship on the performance of SMEs. Journal of Business Research, 69(5), 1780-1784. https://doi.org/10.1016/j.jbusres.2015.10.055

Lumpkin, G. T., \& Dess, G. G. (1996). Clarifying the entrepreneurial orientation construct and linking it to performance. Academy of management Review, 21(1), 135-172.

Lumpkin, G. T., \& Dess, G. G. (2001). Linking two dimensions of entrepreneurial orientation to firm performance: The moderating role of environment and industry life cycle. Journal of business venturing, 16(5), 429-451. https://doi.org/10.1016/S0883-9026(00)00048-3

Mahmood, R., \& Hanafi, N. (2013). Entrepreneurial orientation and business performance of women-owned small and medium enterprises in Malaysia: Competitive advantage as a mediator. International Journal of Business and Social Science (IJBSS), 4(1), 82-90. 
Miller, D., \& Friesen, P. H. (1983). Strategy-making and environment: the third link. Strategic management journal, 4(3), 221-235.

Morgan, N. A., Vorhies, D. W., \& Mason, C. H. (2009). Market orientation, marketing capabilities, and firm performance. Strategic management journal, 30(8), 909-920.

Nurhayati, P., Deliana, Y., Sendjaja, T. P., \& Nurmalina, R. (2020). Pengaruh Orientasi Pasar Terhadap Kinerja Usaha Di Sentra Produksi Ikan Hias Air Tawar Jawa Barat. Jurnal Aplikasi Bisnis dan Manajemen (JABM), 6(1), 51-51.

Priatin, Y., Surya, D., \& Suhendra, I. (2017). Pengaruh Orientasi Pasar Dan Orientasi Kewirausahaan Terhadap Kinerja Pemasaran Dengan Inovasi Produk Sebagai Variabel Intervening (Studi pada Kelompok Usaha Bersama (KUB) Gerabah di Desa Bumi Jaya Kecamatan Ciruas Kabupaten Serang). Jurnal Riset Bisnis dan Manajemen Tirtayasa, 1(1).

Pulendran, S., Speed, R., \& Widing, R. E. (2000). The antecedents and consequences of market orientation in Australia. Australian journal of management, 25(2), 119-143.

Setyawati, H. A. (2013). Pengaruh Orientasi Kewirausahaan dan Orientasi Pasar Terhadap Kinerja Perusahaan Melalui Keunggulan Bersaing dan Persepsi Ketidakpastian Lingkungan Sebagai Prediksi Variabel Moderasi (Survey pada UMKM Perdagangan di Kabupaten Kebumen). Fokus Bisnis: Media Pengkajian Manajemen dan Akuntansi, 12(2).

Slater, S. F., \& Narver, J. C. (1994). Does competitive environment moderate the market orientation-performance relationship?. Journal of marketing, 58(1), 46-55.

Solomon, G. T., Fayolle, A., Carsrud, A., Smallbone, D., Laveren, E., Frank, H., Okamuro, H., Auken, H. Van, Larty, J., Lewis, K., Zealand, N., Shaver, K., Kim, K., Korea, S., Foss, L., Cucculelli, M., Freel, M., Schenkel, M., Grunhagen, M., ... Manager, B. (2016). Journal of Small Business Management.

Souisa, W. (2018). The effects of entrepreneurial orientation and market orientation on business performance. Journal of Entrepreneurship Education, 21(4), 1-6.

Sugiyono. (2014). Metode Penelitian Bisnis. Bandung: Alfabeta

Susila, I. G. A., \& Suparna, G. (2016). Peran Strategi Kepemimpinan Biaya Memediasi Orientasi Pasar Dan” orientasi” kewirausahaan terhadap Kinerja USAha Kecil Menengah (Studi pada USAha Kecil Menengah Laundry di Kota Denpasar). E-Jurnal Manajemen Universitas Udayana, 7(5).

Tarute, A., \& Gatautis, R. (2014). ICT impact on SMEs performance. Procedia-social and behavioral Sciences, 110, 1218-1225. https://doi.org/10.1016/j.sbspro.2013.12.968

Wang, C. L. (2008). Entrepreneurial orientation, learning orientation, and firm performance. Entrepreneurship theory and practice, 32(4), 635-657.

Wicaksono, G., \& Nuvriasari, A. (2012). Meningkatkan kinerja umkm industri kreatif melalui pengembangan kewirausahaan dan orientasi pasar: Kajian pada peran serta wirausaha wanita di kecamatan moyudan, kabupaten sleman, propinsi diy. Jurnal SosioHumaniora, 3(4).

Zhou, K. Z., Brown, J. R., \& Dev, C. S. (2009). Market orientation, competitive advantage, and performance: A demand-based perspective. Journal of business research, 62(11), $1063-1070$. https://doi.org/10.1016/j.jbusres.2008.10.001

Idawati, I. A. A. ., \& Sumartini, A. R. . (2020). The role of development entrepreneurial orientation and market orientation in improving the performance of creative industry SMEs in Denpasar. International Research Journal of Management, IT and Social Sciences, 7(6), 116-123. https://doi.org/10.21744/irjmis.v7n6.1021 